S.G. Buriakovskyi, A.S. Maslii, L.V. Asmolova, N.T. Goncharuk

\title{
MATHEMATICAL MODELLING OF TRANSIENTS IN THE ELECTRIC DRIVE OF THE TURNOUT OF THE MONO-SLEEPER TYPE WITH SWITCHED-INDUCTOR MOTOR
}

\begin{abstract}
Introduction. The study is devoted to the development of the functionality of a railway track switch by introducing a switchedinductor electric drive. This solution justifies simplifying the mechanical part of the switches by changing the gearbox to a ballscrew and locating the all kinematic line of the switches on the mono-sleeper type. Goal. A study of the mono-sleeper turnout type behaviour to meet modern traffic safety requirements and improve operational reliability factors. Methodology. Based on electric drive theory, a kinematic line of a mono-switch turnout type with nonlinear friction characteristic is presented. Using differential equation theory and Laplace transformation, a mathematic description of a four-phase switched-inductor motor with ball-screw in a mechanical line of a single-mass electromechanical system has been made. A simulation mathematical model of the electric drive of mono-sleeper turnout type as the control system with a switched-inductor motor and nonlinear friction characteristic was built in MATLAB. Results. Simulation modelling of a mathematical model of a mono-sleeper turnout type with a switchedinductor motor and ball-screw gear has been developed and implemented. Studies of dynamics of turnout point movement have shown that, in contrast to the motors used today, the switched-inductor motor makes it possible to simplify the mechanical part of the drive, which leads to reduced time spent on laying and maintenance of turnout points, and therefore makes the design more reliable. The application of PID controller and fuzzy speed controller has shown improved dynamics of turnout point, while the fuzzy PID controller provides better performance of the set values and turnout point movements. Originality. First developed a mathematical model of the electric drive of the mono-sleeper turnout type, taking into account nonlinear friction characteristic, as an object of speed control of turnout point movement, is developed. Practical value. The developed mathematical model of a railway track turnout of the mono-sleeper type with a switched-inductor motor and ball-screw gear enables more efficient use of a microprocessor control system, creation of promising electric motor protection means and control of a turnout point. References 18, table 2, figure 14.
\end{abstract}

Key words: switched-inductor electric drive, electromechanical system, control system, fuzzy speed controller.

Робота присвячена розвитку функиіональності залізничного стрілочного переводу иляхом впровадження вентильноіндукторного електроприводу. Таке рімення дає обтрунтування для спрощення механічної частини стрілочного переводу шляхом заміни редуктора на кульково-гвинтову пару, а також розмістити усю кінематичну лінію стрілочного переводу на одній шпалі. Наведено математичний опис чотирифазного вентильно-індукторного двигуна, та спрощеної механічної лінії стрілочного переводу у вигляді одномасової електромеханічної системи. Розроблена імітаційна математична модель електроприводу стрілочного переводу моношпального типу як система підлеглого керування з вентильно-індукторним двигуном, яка враховує нелінійну характеристику навантаження. Наведено результати комп 'ютерного моделювання з ПІД та нечітким регулятором швидкості, які показали, щчо нечіткий ПІД регулятор більш якісно відпрацьовує задані величини та переміщзення гостряків. Бібл. 18 , табл. 2 , рис. 14

Ключові слова: вентильно-індукторний електропривод, електромеханічна система, система керування, нечіткий регулятор швидкості.

Работа посвящена развитию функииональности железнодорожного стрелочного перевода путем внедрения вентильноиндукторного электропривода. Такое решение дает обоснование для упрощения механической части стрелочного перевода путем замены редуктора на шарико-винтовую пару, а также разместить всю кинематическую линию стрелочного перевода на одной шпале. Приведено математическое описание четырехфазного вентильно-индукторного двигателя и упрощенной механической линии стрелочного перевода в виде одномассовой электромеханической системы. Разработанная имитационная математическая модель электропривода стрелочного перевода моношпального типа как система подчиненного управления с вентильно-индукторным двигателем учитывает нелинейную характеристику нагрузки. Приведенные результаты компьютерного моделирования с ПИД и нечетким регулятором скорости показали, что нечеткий ПИД регулятор более качественно отрабатывает заданные величины и перемещения остряков. Библ. 18 табл. 2, рис. 14.

Ключевые слова: вентильно-индукторный электропривод, электромеханическая система, система управления, нечеткий регулятор скорости.

Introduction. One of the main directions of implementation of the National Transport Strategy of Ukraine for the period up to 2030 [1] is the renewal of the transport sector of Ukraine and the gradual harmonization of existing Standards and policies in this area with existing ones in the European Union. Among the main goals and objectives for the development of the transport sector is the development of the railway transport sector, technical capacity of the railway, as there is a threat of failure to meet the needs of Ukraine's economy in transportation and the impossibility of passenger traffic.

Today, the technical resource of the railway is almost exhausted, about 11 thousand $\mathrm{km}$ of railway tracks (about $30 \%$ of the total length) require overhaul and reconstruction, there is a low speed of trains, exacerbated by the wear of tracks that are in critical condition. The load intensity of Ukrainian railways (annual volume of traffic per $1 \mathrm{~km}$ ) is 3-5 times higher than the corresponding rate of developed European countries [2].

That is why in the field of railway transport one of the priority areas of formation and implementation of state policy is the transfer of the industry to the European level, renewal and modernization of fixed assets; technical and technological modernization of railway

C S.G. Buriakovskyi, A.S. Maslii, L.V. Asmolova, N.T. Goncharuk 
transport, increasing the level of safety of railway transportation, modernization of track facilities.

The implementation of these areas of technical and technological modernization of railway transport will help increase the level of safety and quality of railway transport, ensure the efficient operation and development of railway transport.

A special role is given to the quality of operation of turnouts. The search for ways to improve the performance of their operation concerns the modernization or replacement of the electric motor [3], the introduction of new types of sensors and mechanisms for locking the sharps [4].

In [5] the improvement of the dynamics of operation and the expansion of the functionality of railway automation were considered by means of adjustable electric drive on the example of the switch SP-6m based on a DC motor, because in Ukraine, unfortunately, drives of this type are still used.

The development of railway transport, increasing the mass of trains and increasing the speed of their movement have led to the need to use drives with AC motors [6]. Induction three-phase $\mathrm{AC}$ motors have a number of advantages over DC motors with serial excitation, namely the absence of such a complex and unreliable unit as a collector, which significantly reduces operating costs for maintenance and repair. At present, AC electric motors of the MCT type are used on the railway [7].

In [8] a mathematical model of the turnout SP-6m was developed, which is quite widely used in Ukraine, based on DC and AC motors.

Further modernization of domestic turnouts requires replacement of existing drive designs, which are already morally and technically obsolete. These systems have shown their efficiency in many years of practice, but today they can not meet the new requirements for highspeed rail transport. Therefore, the need to modernize switch systems is obvious and should be carried out by means of electric drive [9-11].

Along with the improvement of existing electric switches by replacing unreliable elements and electric motors, global companies are working to create new types [12]. Increasingly, turnouts are equipped with a modified drive system with microcontroller control.

The Bombardier Transportation [13] EBI Switch 2000 electric drive is a non-detachable built-in sleeper (Fig. 1) which is the best example of a sleeper drive to date.

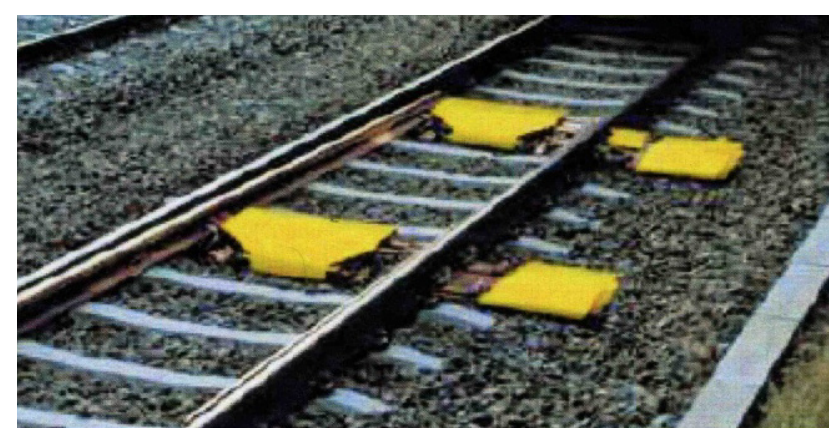

Fig. 1. General view of the EBI Switch 2000 turnout
A feature of EBI Switch 2000 is the presence in the design of a programmable frequency converter. Its application allows to carry out uniform start and braking of the motor, to control current and to stop the motor in case of impossibility of the fine-tuning of wits for a certain time of transfer. Figure 2 shows a diagram of the layout of the turnout EBI Switch 2000, where the following designations are accepted: 1 - electric motor; 2 - frequency converter; 3 - reducer; 4 - shaft with screwnut transmission.

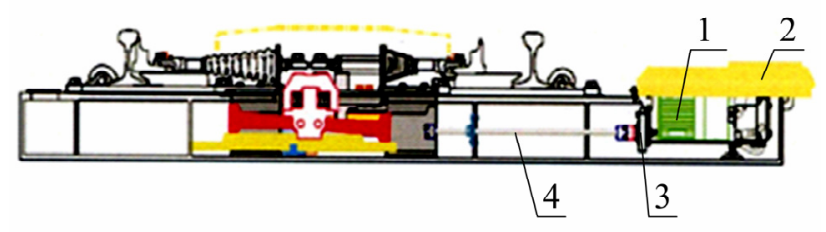

Fig. 2. The layout of the EBI Switch 2000 turnout

Any component of the EBI Switch 2000 system can be replaced in less than 15 minutes without removing the sleeper. The electric drive of this type does not require scheduled maintenance and repair. EBI Switch 2000 is tested in operation for about $10^{6}$ cycles without failures. The average time to failure is $10-15$ years.

Along with the development and implementation of microprocessor devices and the creation of modern lowmaintenance equipment, creation of new types of switches that should ensure maximum reliability and safety of both normal and high-speed traffic and would reduce installation and maintenance time and costs due to abandonment of pre-assembly on an auxiliary platform is an important task.

The goal of the work is the study of the behaviour of the turnout operation of the mono-sleeper type to ensure modern requirements for traffic safety and improve operational reliability.

To achieve this goal the following tasks are formulated:

- to develop a mathematical model of a mono-sleeper switch with a switched-inductor motor and a ball-screw pair as a promising element of the automation system for express and high-speed electric railways;

- to develop a simulation model of a new switch design, which is obtained by replacing the old type of gearbox with a ball-screw pair, which allows to place the entire design of the switch in the sleeper and reduces the size and installation time;

- on the basis of the proportional-integral-differential (PID) speed regulator synthesized in [14], as well as the fuzzy regulator to investigate the dynamic processes in the turnout of the mono-sleeper type to improve its operation in both normal and transient modes.

Research material. For comparison, the electric drive of the switch type SP-6m (Fig. 3) is chosen, the kinematic scheme of which is given in [5], consisting of an electric motor (EM), a reducer with a built-in clutch of friction type and a gate located inside the housing.

Voltage is applied to the EM to switch turnout. Its shaft begins to rotate through the coupling of the gear shaft 2 of the gearbox, located in the housing 1 of the manual transmission (Fig. 4). The gear shaft with the gear 3 forms 
the first transmission stage. The rotation from the gear 3 through the intermediate gear 6 is transmitted to the gear 12 (the second stage). Through the friction located in the housing 1 , the rotation is transmitted to the third transmission stage - the gear shaft 11 and the gear 5 of the main shaft 10 .

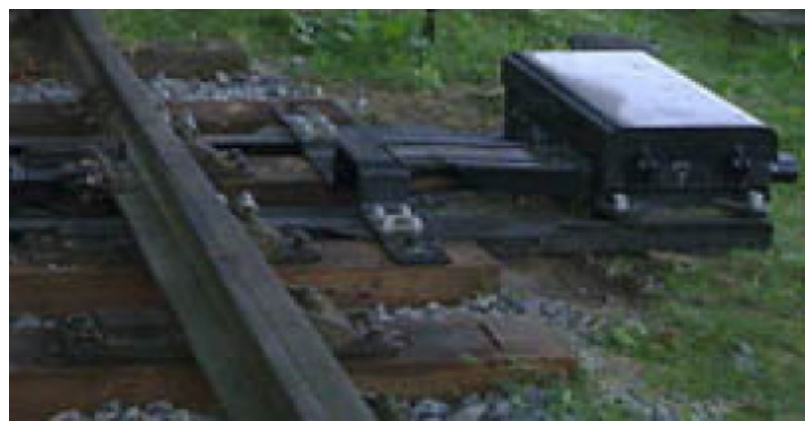

Fig. 3. External view of the SP-6m turnout

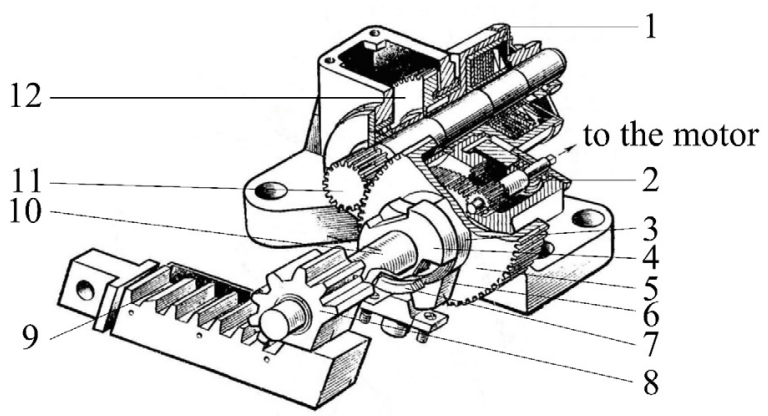

Fig. 4. Mechanical transmission of the SP-6m turnout

The sliding gear 8 , which is made integral with the main shaft, moves the slide 9 (the fourth transmission stage). The gear 5 is freely mounted on the main shaft, the protrusion of which after turning at an angle of $46^{\circ}$ comes into contact with the disk of the main shaft. Thus, the idling of the drive is $46^{\circ}$. The gear 5 has a trapezoidal protrusion to limit the rotation of the wheel. The presence of a technological gap of $46^{\circ}$ is necessary to facilitate the acceleration of the motor and the supply of some kinetic energy in order to disrupt the sharps at the beginning of the transmission process.

Thus, the mechanical transmission allows to obtain the required speed of rotation of the main shaft and the torque of the required value and transmits the rotational motion of the armature to the working rail (gate), converting it into translational motion to transfer the arrowheads. But its design is quite complex, which reduces the overall reliability of the system.

To simplify the design of the turnout, the kinematic link was replaced by a «screw-nut» transmission, which converts the rotational movement of the screw into a translational movement of the nut. This transmission allows to significantly increase the transmission force without increasing the power of the motor [15]. Transmissions of this type have additional losses of friction, but this problem is solved by using a ball-screw pair «screw-nut» (Fig. 5), which has better performance and is used for more accurate movements of sharpeners than conventional screw one.

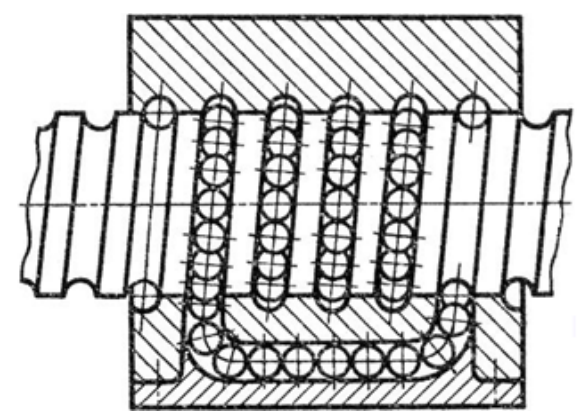

Fig. 5. Ball-screw pair «screw-nut»

The advantages of this pair are that it operates with low friction losses (due to rolling), high transmission efficiency, because the torque from the screw to the nut is transmitted through the balls in the nut. Rotation of the screw causes the nut with the balls to move in a horizontal plane. The nut is connected to the carriage, which in turn moves the slide through a mortise device, which is springloaded with a ball.

The modernization also consists in the fact that the authors of the paper propose to replace the DC or AC motor with a switched-inductor motor (SIM) [16, 17]. Because compared to an induction motor, the SIM has a higher starting torque, and with a DC motor - it does not require periodic maintenance and replacement of brushes in the collector-brush assembly, because it is absent. Thus, SIM has design and operational advantages that allow to predict that such machines will help not only to simplify the mechanical part of the drive and the control system of sharps, but also to increase its reliability and speed. In addition, they are the cheapest in production.

The functional diagram of SIM is shown in Fig. 6, which includes three units: an electromechanical power converter (EPF), an electronic switch (ES) and a control unit $(\mathrm{CU})$ as part of the control module $(\mathrm{CM})$ and a rotor position sensor (RPS) as part of the auxiliary equipment unit that controls by moving the sharpshooters. The control unit protects the motor from overloads (current, temperature ones) and controls the electronic switch.

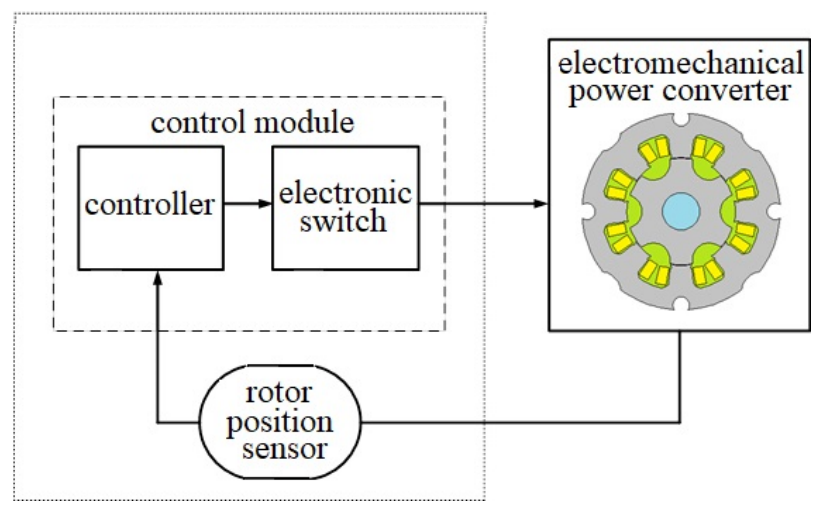

Fig. 6. Functional diagram of the electric drive with SIM

The 4-phase SIM with geometry $8 / 6$ was chosen as a basis, its mathematical model is described by system of differential equations: 


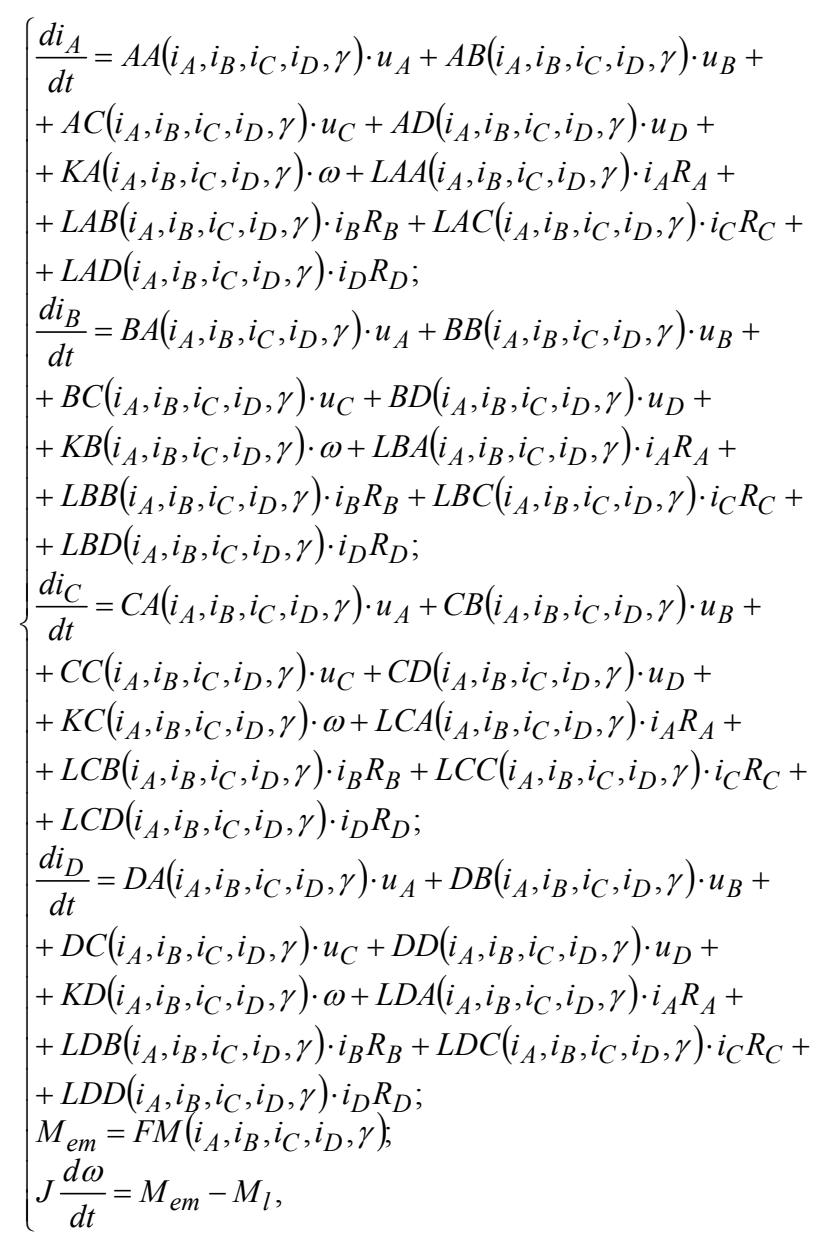

where $i_{A}, i_{B}, i_{C}, i_{D}, \gamma$ are the currents of phases $A, B, C, D$ respectively and the rotor rotation angle; $u_{A}, u_{B}, u_{C}, u_{D}$ are the phase voltages; $A A, A B, A C, A D, B A, B B, B C, B D$, $C A, C B, C C, C D, D A, D B, D C, D D$ are the phase voltage coefficients; $K A, K B, K C, K D$ are the coefficients of angular speed of rotation; $L A A, L A B, L A C, L A D, L B A$, $L B B, L B C, L B D, L C A, L C B, L C C, L C D, L D A, L D B$, $L D C, L D D$ are the phase current coefficients; $R_{A}, R_{B}, R_{C}$, $R_{D}$ are the active resistances of the corresponding phases of the motor; $F M$ is the motor torque coefficient; $J$ is the moment of inertia of the rotor; $\omega$ is the angular speed of the motor; $M_{e m}, M_{l}$ are the electromagnetic moment of the motor and the static moment of loading, respectively.

All the considered coefficients are complex functions that depend on the phase currents and the angle of rotation of the motor rotor.

The use of a new type of electric motor in combination with a ball-screw pair allows to place the entire drive structure in a hollow sleeper, which reduces losses in the gearbox, reduces the size of the switch and simplifies the task of installation or replacement, as well as increases reliability and reduces operating costs. The design of such a turnout is shown in Fig. 7, where a SIM (1) with an electromechanical power converter (2), an electronic switch, which is part of the control module (3) and a rotor position sensor, which is located in the auxiliary equipment unit (4) are separated by a dotted line.

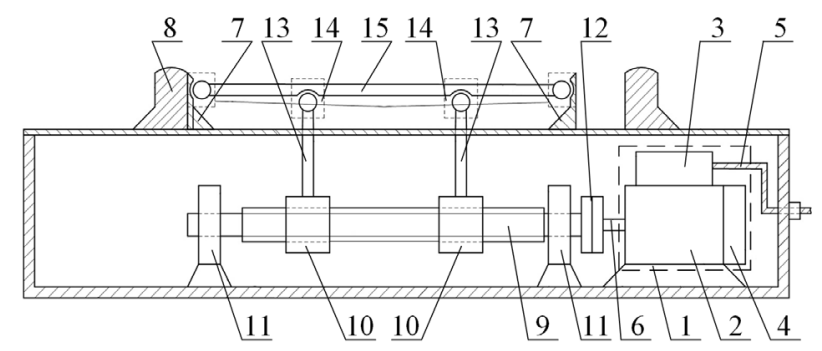

Fig. 7. Constructive scheme of turnout of mono-sleeper type

Depending on the signal of the rotor position sensor, the electronic switch connects the motor phase to the power supply via the cable (5). In this case, the electromechanical power converter (2) converts electrical energy into mechanical energy, driving the shaft of the machine (6). The ball-screw pair «screw-nut» converts the rotational movement of the screw (9) into the translational motion of the nuts (10). The screw is mounted on the support bearings (11) and connected to the motor shaft via a coupling (12). Nuts through vertical rods (13), hinges (14) and longitudinal rod (15) transmit forces to the sharpeners (7), which carry out their movement between the frame rail (8) [18].

To study the processes occurring in the mechanical part of the turnout of the mono-sleeper type, a mathematical simulation model (Fig. 8) was created according to the constructive scheme (Fig. 7), taking into account all the elements, parameters and connections between them.

In contrast to [8], where the kinematic line of the turnout was considered by two-mass and three-mass systems, the mechanical part of the turnout of the monosleeper type is considered as a single electromechanical system, i.e. a single-mass one (Fig. 9). This can be considered given that the force to the longitudinal thrust from the nuts is transmitted through two vertical thrusts (the force to the longitudinal thrust is applied at two points), as well as neglect the gaps in the joints, because they appear only in the process of their making.

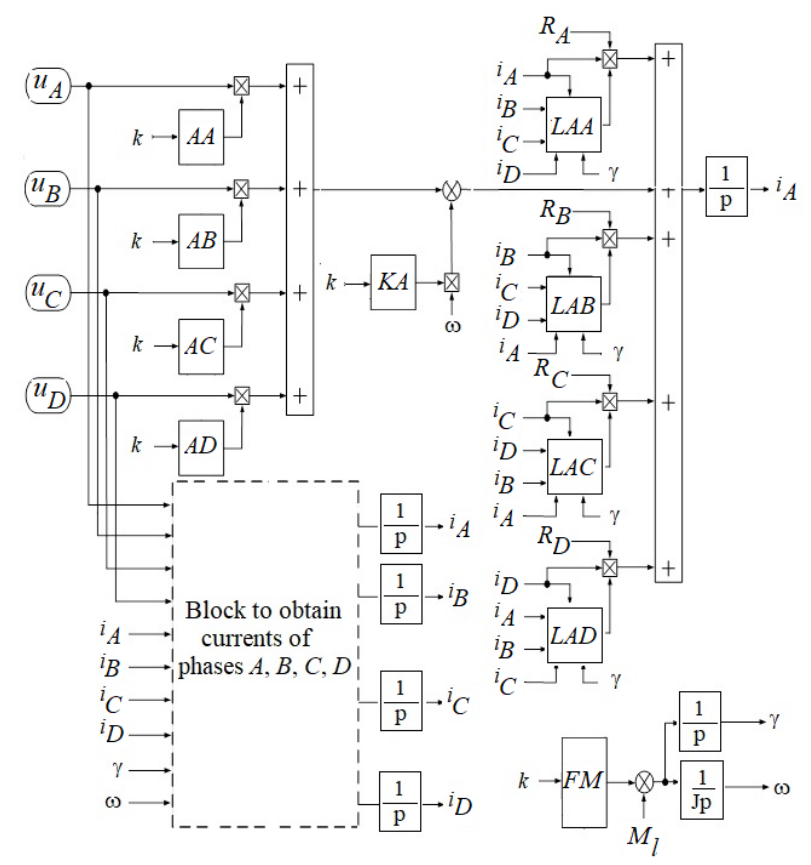

Fig. 8. Block diagram of the turnout of the mono-sleeper type 


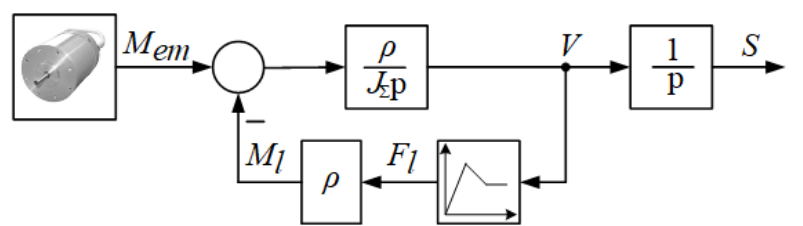

Fig. 9. Block diagram of the mechanical transmission of the turnout of the mono-sleeper type

Block diagram of Fig. 9 has a total reduced moment of inertia to the electric motor $J_{\Sigma}$, which consists of the moments of inertia of the SIM rotor, the transmission «screw-nut» and the masses of the sharps. In the feedback system there is a load unit $V=f\left(F_{l}\right)$, which reflects the characteristics of friction, because the switches operate in different weather conditions under the influence of random factors (fallen leaves, rain, snow, substances that fall out of cars, etc.). The average values of the coefficient of friction on the surface of the rail-cushion (steel-steel) are given in Table 1 .

Table 1

\begin{tabular}{|c|c|c|c|c|}
\multicolumn{4}{c|}{ Coefficient of friction at rest and sliding } \\
\cline { 2 - 5 } Rubbing & \multicolumn{3}{|c|}{ Coefficient of friction } \\
\cline { 2 - 5 } materials & \multicolumn{2}{|c|}{ at rest } & \multicolumn{2}{c|}{ at sliding } \\
& $\begin{array}{c}\text { without } \\
\text { lubrication }\end{array}$ & $\begin{array}{c}\text { with } \\
\text { lubrication }\end{array}$ & $\begin{array}{c}\text { without } \\
\text { lubrication }\end{array}$ & $\begin{array}{c}\text { with } \\
\text { lubrication }\end{array}$ \\
\hline $\begin{array}{c}\text { rail- } \\
\text { cushion }\end{array}$ & 0,8 & $0,5-0,4$ & $0,15-0,3$ & $0,05-0,18$ \\
\hline
\end{tabular}

The control system of the turnout of the monosleeper type is considered as a system of subordinate control of coordinates with PID and fuzzy PID speed regulators, which together with SIM is reduced to the general simulation model in Fig. 10, and Fig. 11 shows a diagram of the mechanical part.

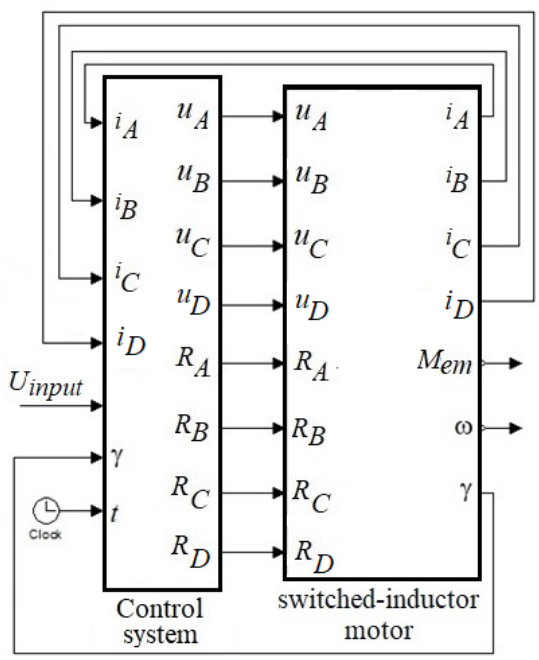

Fig. 10. Generalized SIM simulation model with control system

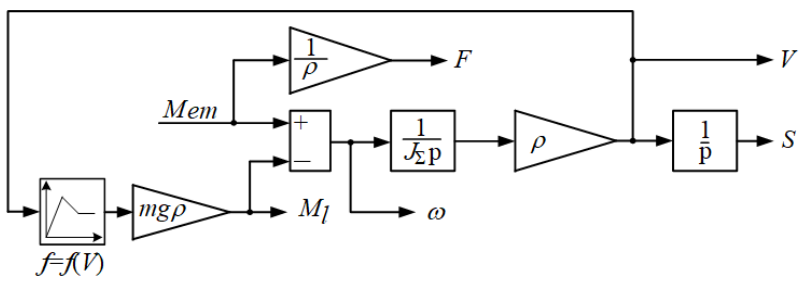

Fig. 11. Simulation model of the mechanical part of the turnout of the mono-sleeper type
The operation of the turnout of the mono-sleeper type was studied at a constant load, taking into account the friction characteristic, which most negatively affects the process of transfer of sharps. As a result of simulation of the kinematic line of the turnout, oscillograms of the distribution of traction force on the sharpeners $F=f(t)$, the speed of their transmission $V=f(t)$ and displacement $S=f(t)$, are obtained and shown in Fig. 12 .
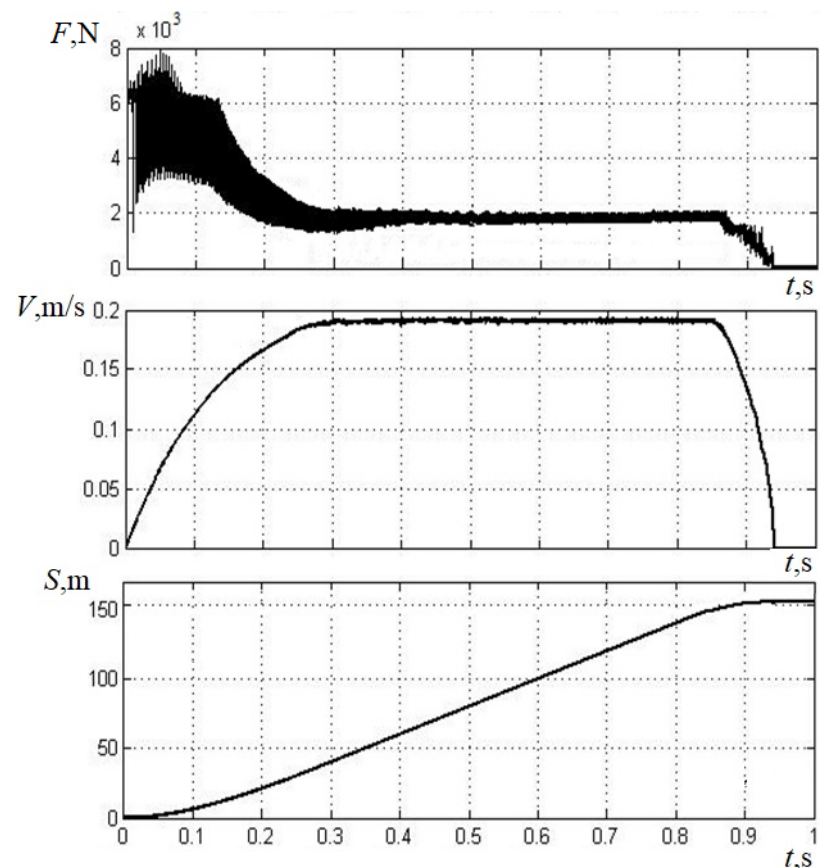

Fig. 12. Transients in mechanical transmission of mono-sleeper turnout

The obtained results show that in the kinematic line of the turnout there are fluctuations of the traction force, the amplitude of which in comparison with the traditional turnout has decreased by 5.5-6 times [8]. Such oscillations depend to a greater extent on the nature of the behaviour of the electromagnetic torque.

Figures 13, 14 show the transients of the electric drive operation, namely the electromagnetic torque and speed with PID speed controller (Fig. 13) and with fuzzy PID speed controller (Fig. 14) with additional constant load at $t=0.6 \mathrm{~s}$.

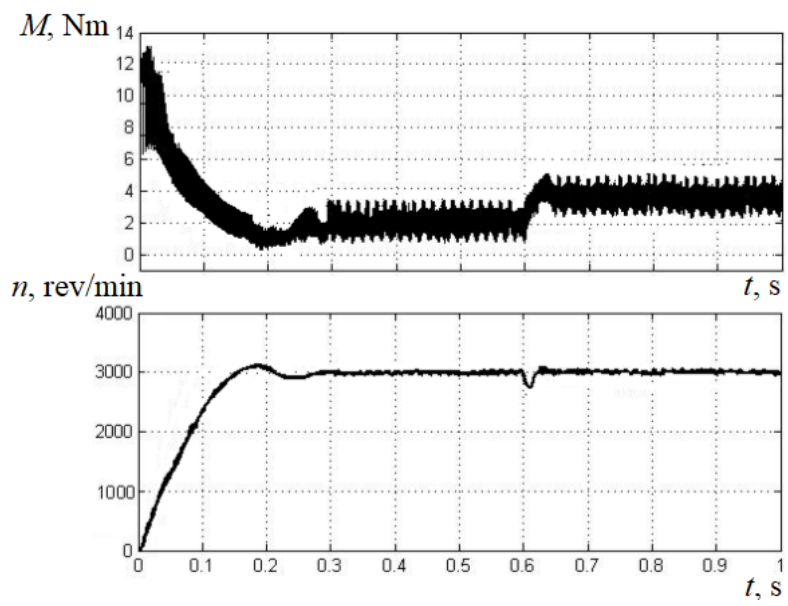

Fig. 13. Transients in turnout of mono-sleeper type with PID speed regulator 


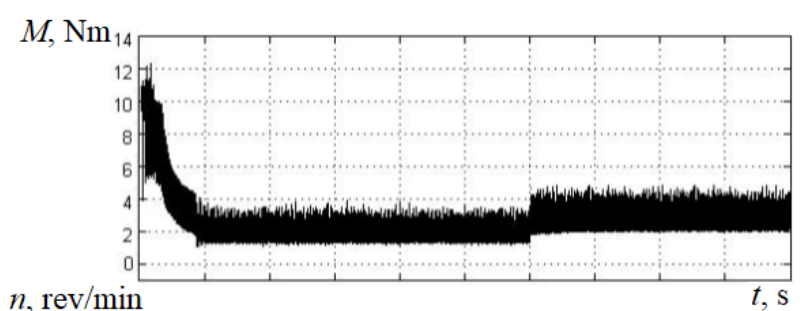

$n, \mathrm{rev} / \mathrm{min}$

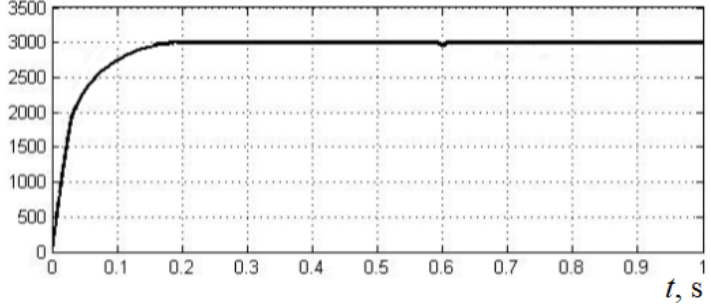

Fig. 14. Transients in the turnout of the mono-sleeper type with fuzzy PID speed controller

From the obtained graphs of transients it is established that the highest quality transient process corresponds to the system with fuzzy PID speed controller (Fig. 14), because the motor speed reaches a constant level without overregulation in contrast to the use of PID speed controller (Fig. 13). The main indicators of the quality of regulators are given in Table 2 .

Table 2

Main indicators of the quality of regulatory processes

\begin{tabular}{|c|c|c|}
\hline Quality indicator & PID regulator & $\begin{array}{c}\text { Fuzzy PID } \\
\text { regulator }\end{array}$ \\
\hline Overregulation $\sigma_{\max }, \%$ & 4,2 & 0 \\
\hline Adjustment time $t_{s}, \mathrm{~s}$ & 0,27 & 0,17 \\
\hline Number of oscillations $N$ & 1 & 0 \\
\hline
\end{tabular}

In addition, the proposed type of turnout works out a given movement of sharps for up to $1 \mathrm{~s}$, which is crucial in terms of its use for high-speed rail transport.

\section{Conclusions.}

1. Using the developed mathematical model of monosleeper turnout with a switched-inductor motor and a ballscrew pair, a study of the dynamics of the movement of sharps in the MATLAB environment was performed. The results showed that the transition from the traditional turnout to the mono-sleeper type is justified. Unlike electric motors in use today, SIM has design advantages to simplify the mechanical part of the drive, as well as the control system of sharpeners. This has improved the quality of the dynamics of the turnout, which ensures the reliability and safety of both normal and high-speed rail transport.

2. Structural simplification of the kinematic transmission is performed by eliminating the intermediate gearbox in the existing EBI Switch 2000 turnout, which reduces the time spent on installation and maintenance of the switch, as well as makes the design more reliable.

3. The transition to a mono-sleeper turnout allows to more effectively apply the microprocessor control system, create promising means of electric motor protection and ensure control of the position of the sharps.

4. The use of PID and fuzzy PID speed regulators in the control system, taking into account the nonlinear characteristic of friction, showed an improvement in the dynamics of the turnout. In a system with a fuzzy PID controller, not only the transmission speed has increased, but there is also a better process of operation of a monosleeper type turnout with SIM.

Conflict of interest. The authors declare no conflict of interest.

\section{REFERENCES}

1. Pro skhvalennia Natsionalnoi transportnoi stratehii Ukrainy na period do 2030 roku: rozporiadzhennia Kabinetu Ministriv Ukrainy vid 30 travnia 2018 r. № 430-r [On approval of the National Transport Strategy of Ukraine for the period up to 2030. Order of the Cabinet of Ministers of Ukraine of May 30, 2018 № 430-r]. Available at: https://zakon.rada.gov.ua/go/4302018-\%D1\%80 (Accessed 20.10.2020). (Ukr).

2. Ministerstvo infrastruktury Ukrainy. Informatsiia pro ukrainski zaliznytsi [Ministry of Infrastructure of Ukraine. General information about railway transport]. Available at: https://mtu.gov.ua/en/content/informaciya-pro-ukrainskizaliznici.html (Accessed 20.10.2020). (Ukr).

3. Kande M., Isaksson A., Thottappillil R., Taylor N. Rotating Electrical Machine Condition Monitoring Automation - A Review. Machines, Oct. 2017, vol. 5, no. 4, p. 24. doi: https://doi.org/10.3390/machines5040024.

4. Bemment S.D., Goodall R.M., Dixon R., Ward C.P. Improving the reliability and availability of railway track switching by analysing historical failure data and introducing functionally redundant subsystems. Proceedings of the Institution of Mechanical Engineers, Part F: Journal of Rail and Rapid Transit, Sep. 2017, vol. 232, no. 5, pp. 1407-1424. doi: https://doi.org/10.1177/0954409717727879.

5. Buriakovskyi S., Smirnov V., Asmolova L., Obruch I., Rafalskyi O., Maslii A. Analysis of optimization criteria for the process of switch displacement in a DC railroad turnout. EasternEuropean Journal of Enterprise Technologies, Dec. 2019, vol. 6, no. 2 (102), pp. 58-69. doi: https://doi.org/10.15587/17294061.2019.187580.

6. Fathy Abouzeid A., Guerrero J.M., Endemaño A., Muniategui I., Ortega D., Larrazabal I., Briz F. Control strategies for induction motors in railway traction applications. Energies, Feb. 2020, vol. 13, no. 3, p. 700. doi: https://doi.org/10.3390/en13030700.

7. Dorohin B.P., Serdyuk T.M. Implementation of new types of points motors. Electromagnetic compatibility and safety on railway transport, 2013, no. 6, pp. 71-84. Available at: http://ecsrt.diit.edu.ua/article/view/51291 (Accessed 20.10.2020). (Rus). 8. Buriakovskyi S.G., Maslii A.S., Pasko O.V., Smirnov V.V. Mathematical modelling of transients in the electric drive of the switch - the main executive element of railway automation. Electrical Engineering \& Electromechanics, 2020, no. 4, pp. 1723. doi: https://doi.org/10.20998/2074-272X.2020.4.03.

9. Lagos R.F., San Emeterio A., Vinolas J., Alonso A., Aizpun $M$. The influence of track elasticity when travelling on a railway turnout. Proceedings of the Second International Conference on Railway Technology: Research, Development and Maintenance, 2014, p. 11. doi: https://doi.org/10.4203/ccp.104.208.

10. Kuznetsov B.I., Nikitina T.B., Kolomiets V.V., Bovdui I.V. Improving of electromechanical servo systems accuracy. Electrical Engineering \& Electromechanics, 2018, no. 6, pp. 3337. doi: https://doi.org/10.20998/2074-272X.2018.6.04.

11. Moiseenko V.I., Poddubnyak V.I. Avtomatika i komp'iuternye sistemy na stantsiiakh [Automation and computer systems in stations]. Kiev, Transport of Ukraine Publ., 1999. 142 p. (Rus).

12. Arslan B., Tiryaki H. Prediction of railway switch point failures by artificial intelligence methods. Turkish journal of electrical engineering \& computer sciences, Mar. 2020, vol. 28, no. 2, pp. 1044-1058. doi: https://doi.org/10.3906/elk-1906-66.

13. Sokol Y.I., Buryakovskiy S.G., Masliy Ar.S. Energy-efficient electric drive of multifunctional turnout. Problemy Kolejnictwa, 2014, no. 165, pp. 99-107. Available at: http://atena.ikolej.pl/images/PDF/165 8.pdf (Accessed 20.10.2020). 14. Buriakovskyi S., Maslii A., Pasko O., Denys I. Research and development of an electric traction drive based on a switched 
reluctance motor. Transport Problems, 2018, vol. 13, no. 2, pp. 69-79. doi: https://doi.org/10.20858/tp.2018.13.2.7.

15. Li F., Jiang Y., Li T., Du Y. An improved dynamic model of preloaded ball screw drives considering torque transmission and its application to frequency analysis. Advances in Mechanical Engineering, 2017, vol. 9, no. 7, p. 168781401771058. doi: https://doi.org/10.1177/1687814017710580.

16. Buriakovskyi S., Babaiev M., Liubarskyi B., Maslii A., Karpenko N., Pomazan D., Maslii A., Denys I. Quality assessment of control over the traction valve-inductor drive of a hybrid diesel locomotive. Eastern-European Journal of Enterprise Technologies, 2018, vol. 1, no. 2 (91), pp. 68-75. doi: https://doi.org/10.15587/1729-4061.2018.122422.

17. Sezen S., Karakas E., Yilmaz K., Ayaz M. Finite element modeling and control of a high-power SRM for hybrid electric vehicle. Simulation Modelling Practice and Theory, Mar. 2016, vol. 62, pp. 49-67. doi: https://doi.org/10.1016/j.simpat.2016.01.006.

18. Buriakovskyi S.H., Maslii Ar.S., Maslii An.S. Elektropryvid strilochnoho perevodu [Electric switch point drive]. Patent UA, no. 95497, 2014. (Ukr).

Received 20.01.2021

Accepted 22.02.2021

Published 05.04.2021
S.G. Buriakovskyi ${ }^{1}$, Doctor of Technical Science, Professor, A.S. Maslii ${ }^{2}$, PhD, Associate Professor,

L.V. Asmolova ${ }^{3}, P h D$,

N.T. Goncharuk ${ }^{4}$, Doctor of Science in Public Administration,

Professor,

${ }^{1}$ Research and Design Institute «Molniya»

of National Technical University

«Kharkiv Polytechnic Institute»,

47, Shevchenko Str., Kharkiv, 61013, Ukraine,

e-mail: sergbyr@i.ua

${ }^{2}$ Ukrainian State University of Railway Transport,

7, Feierbakh Square, Kharkiv, 61050, Ukraine,

e-mail: a.masliy@ukr.net

${ }^{3}$ National Technical University «Kharkiv Polytechnic Institute», 2, Kyrpychova Str., Kharkiv, 61002, Ukraine, e-mail: asmolova_larisa@ukr.net

${ }^{4}$ Dnipropetrovsk Regional Institute for Public Administration, National Academy for Public Administration

under the President of Ukraine,

29, Gogol Str., Dnipro, 49044, Ukraine,

e-mail: goncharuknt@gmail.com

How to cite this article:

Buriakovskyi S.G., Maslii A.S., Asmolova L.V., Goncharuk N.T. Mathematical modelling of transients in the electric drive of the turnout of the mono-sleeper type with switched-inductor motor. Electrical Engineering \& Electromechanics, 2021, no. 2, pp. 16-22. doi: 10.20998/2074-272X.2021.2.03. 